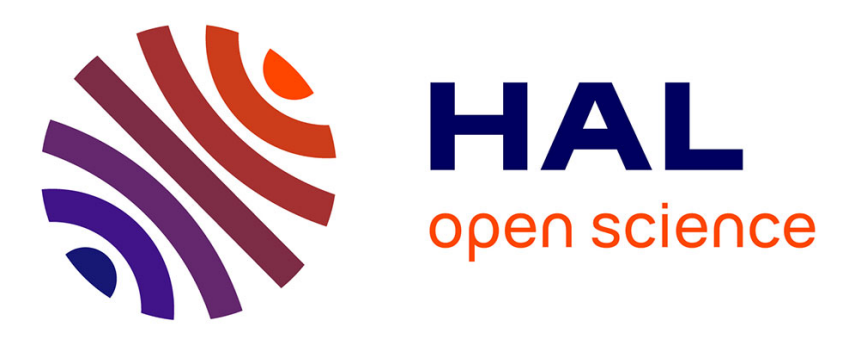

\title{
Policy making as collective bricolage: the role of the electricity sector in the making of the European carbon market
}

\author{
Mélodie Cartel, Eva Boxenbaum, Franck Aggeri, Jean-Yves Caneill
}

\section{- To cite this version:}

Mélodie Cartel, Eva Boxenbaum, Franck Aggeri, Jean-Yves Caneill. Policy making as collective bricolage: the role of the electricity sector in the making of the European carbon market. Christina Garsten, Adrienne Sörbom. Power, policy and profit: corporate engagement in politics and governance, Edward Elgar, 2017, 978-1-78471-120-7. hal-01615460

HAL Id: hal-01615460

https://hal-mines-paristech.archives-ouvertes.fr/hal-01615460

Submitted on 12 Oct 2017

HAL is a multi-disciplinary open access archive for the deposit and dissemination of scientific research documents, whether they are published or not. The documents may come from teaching and research institutions in France or abroad, or from public or private research centers.
L'archive ouverte pluridisciplinaire HAL, est destinée au dépôt et à la diffusion de documents scientifiques de niveau recherche, publiés ou non, émanant des établissements d'enseignement et de recherche français ou étrangers, des laboratoires publics ou privés. 


\section{Policymaking as collective bricolage: the role of the electricity}

sector in the making of the European carbon market

Mélodie Cartel (Grenoble école de management), Eva Boxenbaum \& Franck Aggeri (CGS-i3, UMR 9217, MINES ParisTech, PSL Research institute) and Jean-Yves Caneill (EDF, R\&D)

In: Garsten, K. \& Sorbom, A. (eds) ; Power, Policy and Profit: Corporate Engagement in Politics and Governance, Edward Elgar, 2017. 


\section{INTRODUCTION}

How can public policies be designed and implemented when they face strong reluctance from both the politicians that make them and the private corporations that influence them? This question is particularly vivid in the case of the European carbon market (EU-ETS). ${ }^{1}$ The EUETS was adopted in 2003 as the corner stone of the European climate policy. Its development countered both the European Commission's intellectual convictions and the interests of industrial stakeholders (Newel and Paterson 1996; Wettestad 2005). Despite abundant scholarly work in multiple disciplines (Braun 2009; Cass 2005; Christiansen and Wettestad 2003; Damro and Mendez 2003), the making of the EU-ETS still represents a conundrum yet to be explained.

The failure to fully explain the making of the EU-ETS is partly linked to the lack of detailed empirical accounts of the policymaking process. The case of the EU-ETS epitomizes a general situation in the analysis of policymaking (Tyllström this volume). The lack of empirical case studies has limited the understanding of how corporations and policymakers interact and collectively shape public policies. Indeed, the tactics that corporations use to exert influence on the political sphere have become an academic blind spot. On the one hand, the research stream on corporate political activities focuses on corporations' internal motivations for influencing policymaking (Baron 1995, 1999; Baron and Diermeier 2007; Bonardi et al., 2005; Holburn and Vanden Bergh 2008). On the other hand, political scientists are primarily interested in governmental activities and less in strategic corporate action. So far, the collective dynamics of policymaking and how corporations manage to provoke radical opinion shifts during policymaking have been overlooked. 
In an effort to address this blind spot, we pose the following question: How do private corporations provoke radical opinion shifts during policymaking processes?

To address this question, we reopen the case of the making of the European carbon market with unprecedented empirical elements. Drawing on a rich set of archival data and interviews, we reconstitute the original strategy deployed by the electricity sector to implement a carbon market in Europe. During the Kyoto Protocol, the European Commission opposed emissions trading (Cass 2005; Convery 2009; Damro and Mendez 2003; Skjærseth and Wettestad 2008; Wettestad 2005). As for industrial companies, they pleaded against any measure involving a price on carbon (Newell and Paterson 1996, 1998). Nevertheless, a handful of actors in the electricity sector believed that a carbon market could be an effective solution to manage carbon emissions at the company level. From 1999 to 2001, these actors organized two successive experiments where they invited industrial companies to build and test various carbon market prototypes. Our interviews indicate that these experiments triggered an intellectual shift among participants and considerably fuelled the policymaking process that led to the EU-ETS.

In this chapter, we discuss two aspects characterizing policymaking in the case of the EU-ETS. First, building on the literature on bricolage (Duymedjian and Rüling 2010; LéviStrauss 1962, 1966), we describe the role of collective bricolage as a key process for reaching consensus. The Greenhouse Gas and Electricity Trading Simulation (GETS) participants felt involved in the design of the market instrument as they had a possibility to add new features to the market's design and reshuffle its existing architecture. Collective bricolage proved key to gain participants' confidence as well as to ensure that the participants' interests were represented in the market design. Secondly, we describe the role of staging demonstrations of policy innovations. Staging an experimentation of carbon markets with a restricted community demonstrated both their economic and environmental value. Such 
experimentation might not have taken place in more formal political arenas. Yet, it imbued carbon markets with legitimacy at a large scale. We believe that the concepts of bricolage and staging carry the potential to open new academic avenues in the analysis of policymaking.

\section{THE SETTING}

The empirical setting of this study is the Greenhouse Gas and Electricity Trading Simulation (GETS), an experiment organized by the European electricity sector to generate and test alternative designs for carbon markets. Eurelectric, the Union of the European Electricity Industry, organized two GETS: GETS1 in 1999 involved only the electricity sector while GETS2 in 2000 involved all the main stakeholders of the forthcoming European climate policy. Both in GETS1 and 2, Eurelectric invited a closed number of companies to participate in a role play on prototype carbon markets.

The original idea for organizing an industry-wide role play on carbon markets stemmed from a small group of colleagues at Eurelectric in 1998. After a conference on emission trading, members of the small group challenged each other to imagine rules for a carbon market that could be implemented in Europe. That afternoon, they sat down with a whiteboard and wrote the rules of the first carbon market prototype. Before returning home the small group agreed that it would be an opportunity to conduct a sector-wide role play on carbon markets so that electric utilities could learn more about these policy instruments. Consequently, they hired economists and experts to help them refine the rules they had imagined and organized a role play with the European electricity utilities. The initially smallscale initiative ended up two years later mobilizing all the main stakeholders of European Climate policy: top ranked economists and climate policy experts, members of the European 
Commission in charge of elaborating European climate policy, more than 40 major private companies in Europe and financial institutions. How did this wide-scale mobilization occur, given the initial reluctance of key stakeholders?

\section{GLOBAL POLITICAL CONTEXT}

Following the 1997 Kyoto conference on climate change, the European electricity sector mobilized itself to address the climate issue. Given the legally binding nature of the Kyoto targets on carbon emissions, the electricity sector expected the European Commission to rapidly introduce a new policy instrument to support its climate change mitigation programme. Consequently, some members of the electricity sector sensed that a carbon market would soon be on the agenda despite the Commission's reluctance:

$<$ quotation $>$ We all came back from Kyoto and we looked at what we were going to do. At that time, the industry's basic view was that we didn't want a tax. What we wanted were voluntary agreements. $[\ldots$. It became clear to us that the marketbased mechanisms within Kyoto were going to drive the Commission towards implementing some kind of constraint on emissions in the power industry. We recognised then that the voluntary agreements were a good idea but were not going to get much political traction. Therefore we had the choice between a tax and some market based mechanisms. (Eurelectric 1, 2015, 22 October)</quotation $>$

The positions taken by European electricity sector companies on market instruments were far from uniform. In some countries, such as the United Kingdom, electricity companies tended 
to be in favour of a carbon market and were already working with their government to prepare pilot domestic markets (Braun 2009). The German companies, in contrast, were strongly opposed to a European carbon market. They were concerned that an agreement at the European level would endanger their efforts to establish voluntary agreements with their own national government (Wettestad 2005). Apart from these two very strong stands on carbon markets from English and German electricity companies, most of European electricity companies shared a somewhat reluctant position toward carbon markets, whether or not this position was officially enacted through active political strategizing. Lastly, the concrete implementation of a carbon market at the European level raised a wide variety of technical, managerial, social and economic questions. For instance, would such a market be compatible with the recently deregulated electricity market? How should companies conduct their business and build consistent strategies in a carbon market? How would the market impact companies' competitiveness? And would companies be accused of buying rights to pollute in order to sidestep their responsibilities?

Eurelectric, the Union of the Electricity Industry, eventually launched the GETS as a way to accelerate collective learning at the sectoral scale, unify the sector's position towards carbon markets and work on a common strategy. Between 1999 and 2001, in a climate of shared uncertainty (Aggeri 1999), Eurelectric designed and tested several prototypes of carbon markets. 


\begin{tabular}{|c|c|c|}
\hline RULES & GETS2.1 & EU-ETS Pilot \\
\hline Market Type & Cap and Trade & Cap and Trade \\
\hline Commodity & 1 quota $=1 \mathrm{tCO}_{2 \mathrm{eq}}$ & 1 quota $=1 \mathrm{tCO}_{2 \mathrm{eq}}$ \\
\hline Coverage & $\begin{array}{l}\text { Energy activities, } \\
\text { Production and } \\
\text { processing of ferrous } \\
\text { metals, Mineral industry, } \\
\text { pulp \& paper industry }\end{array}$ & $\begin{array}{l}\text { Energy activities, } \\
\text { Production and } \\
\text { processing of ferrous } \\
\text { metals, Mineral industry, } \\
\text { pulp \& paper industry }\end{array}$ \\
\hline Scope & 6 Kyoto gases & $\mathrm{CO}_{2}$ \\
\hline \multicolumn{3}{|c|}{ PROCEDURES } \\
\hline Allocation & Grandfathering & Grandfathering \\
\hline Permit Restitution & $\begin{array}{l}\text { End of each engagement } \\
\text { period }\end{array}$ & $\begin{array}{l}\text { End of each engagement } \\
\text { period }\end{array}$ \\
\hline \multicolumn{3}{|c|}{ FLEXIBILITY } \\
\hline \multicolumn{3}{|l|}{ Pricing Mechanisms } \\
\hline Ceiling Price & No & No \\
\hline Threshold Price & No & No \\
\hline \multicolumn{3}{|l|}{ Temporal Flexibility } \\
\hline Banking & Yes & Yes \\
\hline Borrowing & No & No \\
\hline \multicolumn{3}{|c|}{ MONITORING } \\
\hline Penalties & Non-discharging & Non-discharging \\
\hline
\end{tabular}

Table 3.1 EU-ETS/GETS comparison (source: adapted from GETS1 report 1999).

As shown in Table 3.1, the design that Eurelectric co-developed with the rest of the industry and with inputs of the European Commission in GETS2 was very similar to the policy that the European Parliament finally adopted in 2003.

\section{DATA COLLECTION}

We studied the two successive GETS exercises in the period running from 1998 (the year the system was designed) until 2001 (the year the first EU-ETS directive was proposed). We had exclusive access to the archives of the GETS role plays, which remain unpublished: report documents, internal communications and emails, meeting reports, etc. In addition, over a 
three-year period, the first author collected both physical archives classified in the basement of the companies involved in the GETS, and electronic archives.

We supplemented the historical archives with a series of 23 semi-directive interviews (Eisenhardt and Graebner 2007) with key GETS protagonists. These interviews lasted between 30 minutes and two hours. We selected our respondents according to the three types of protagonists that composed GETS:

- organizers of the role play (either members of Eurelectric or actors providing technical support)

- players (representatives of industrial companies - oil, cement, paper, electricity - and financial institutions that volunteered to test the carbon market prototypes)

- external stakeholders (members of the European Commission and economists involved in the making of the carbon market)

The interviewed organizers included: a key decider at Eurelectric, fervent advocate of market mechanisms and the initiator of the role plays; a representative of the International Energy Agency, a specialist in emissions trading and mandated by Eurelectric to help design the market prototypes and the representative of Paris Bourse, specialist in carbon finance who oversaw the role plays.

The interviewed players included representatives of four large electricity companies. One of them was involved from the very beginning in both the design of the prototypes, in the role plays and in the international dissemination of the experiments. We met the representatives of Lafarge and Holcim, two of the largest European cement companies. Highly engaged in climate issues, the representative from Lafarge took part in the role plays 
in order to raise his colleagues' awareness of climate issues and the market mechanisms he strongly felt were needed to deal with these issues. We also met with a representative of Natsource, a financial institution specializing in environmental markets. His goal was to secure the participation of the financial sector in the European carbon market. At the time, the financial sector saw little interest in participating in the various environmental markets. His objective was to demonstrate the importance of participating in the sector in order to establish a 'stable and fair' carbon price. We met two representatives of the paper sector that were quite opposed to carbon markets in the early 2000 as well as a representative of the oil company BP.

Lastly, the interviewed external stakeholders included two economists from the European Commission who at the time of GETS were central actors of the group in charge of the EU-ETS. We also interviewed an economic scholar that was very much involved in climate policy issues at the time, as well as the head of the French think tank Entreprises Pour l'Environnement, that gathers private companies committed to solving environmental issues.

During our investigations we sought to understand the strategic positions taken by the various protagonists on the carbon markets in the period 1999 to 2001 . We focused on changes in their positions over time, including the development of interests and strategies throughout the GETS role plays. This information, which was not available in the archive documents, enabled us to establish the relationship between the role plays and the development of the EU-ETS Directive. Some informants said that the GETS played an implicit cognitive role in the formulation of the EU-ETS Directive. Others perceived the GETS role plays as a deliberate lobbying effort rather than a collective learning experience. Yet others claimed to have been deliberate pioneers of the European carbon market. 


\section{THE CASE STUDY}

\section{GETS1 (1999) - The Electricity Sector Initiating An Experiment}

In December 1998, Eurelectric hired the International Energy Agency to collaborate in the design of a prototype carbon market (see Figure 3.1). The global architecture of the prototype carbon market took inspiration from the $\mathrm{SO}_{2}$ market that had been successfully operating in the United States since 1995. For instance, the attribution of emission allowances was based on the $\mathrm{SO}_{2}$ market model: the regulator distributes emissions allowances to each affected utility on the basis of historical emissions. The possibility for utilities to 'bank' unused allowances also took inspiration from the $\mathrm{SO}_{2}$ market. Banking consists of setting aside allowances received in period A and using them in a further period B. Such an option had proven valuable to the political success of the $\mathrm{SO}_{2}$ market (Burtraw and Szambelan 2009). Indeed, 'once firms have built up a bank of unused allowances, they have a vested interest in maintaining the value of those banked credits and thus in furthering the program itself' (Ibid., p. 6). Aside from adapting these pre-existing principles to the European carbon emissions context, Eurelectric also introduced an original element in the prototype, namely the 'grace period'. The grace period authorizes utilities to comply with their carbon emission objective even after the deadline, in case they have not been able to comply before. The idea behind the grace period is to help companies that failed to reach their carbon emission target, by providing them with some extra time.

Eurelectric also hired Paris Bourse, the French stock exchange to help manage a role play on the prototype carbon market described above. Paris Bourse lent its experimental trading platform to carry out the role play. Indeed, Paris Bourse had designed an experimental trading 
platform to test financial products before launching real markets. The device operated as a simplified stock exchange: to buy carbon, company A would book an order, indicating both a quantity and a proposed price; to sell carbon company B would also book an order, indicating the available quantity of carbon and a selling price. If there was a match, the transaction took place. If not, both buyers and sellers would adjust price expectations by booking another order. Paris Bourse was particularly interested in carbon markets, which it perceived as novel and promising objects. Its main question toward GETS1 prototype was: 'does it allow for the fast emergence of a carbon price?' Celerity of price discovery is crucial from a financial perspective to demonstrate that markets are healthy. Fast price discovery enables economically efficient trading. As shown in Figure 3.1, GETS1 prototype consisted of a series of rules formulated by Eurelectric and the International Energy Agency as well as technical equipment to support carbon and electricity trading provided by Paris Bourse. The IEA was tasked to be the game master.

\section{Staging a Demonstration of the First Prototype}

A total of 19 electricity companies volunteered to take part in the role play proposed by Eurelectric. Each company had to create a virtual profile: choose an energy mix and total installed capacity. This resulted in the formation of 16 virtual companies (some of the players joined forces). The game master set two objectives: to supply enough electricity to meet demand and to achieve a certain carbon emissions reduction target. The role play lasted eight weeks. Every Wednesday at a set time, the companies connected to a computer terminal to carry out the role play. Thirty minutes before the opening of the trading platform, participants received guidelines indicating their objectives as well as some key economic elements (for instance the price of raw material). Staging a demonstration of carbon markets through the 
role play had three types of impacts on the electricity sector's position in the carbon market. First of all, it raised awareness on carbon markets inside the participating companies. Second, it provoked a strategic shift in the industry by demonstrating empirically some desirable properties of carbon markets. Third, it created an atmosphere of camaraderie among the participants that pacified the debates at the sectoral level.

Participants would gather in teams to elaborate various compliance strategies. According to our informants, the need to gather multidisciplinary teams to perform the role play raised awareness on carbon-related issues inside the participating companies:

\footnotetext{
"The exercise also helped us make the issue known in the company because we formed a team from different part of the company. For example we went to the trading people, when I talked to the head of trading at first he almost ruled me out of his office and said 'I have so much work to do here and you come with this stuff. . . !' but pretty quickly he realised that we had a point and he sent one of his people into our simulation group. In our team we had $4-5$ people sitting in front of the computer during the trading sessions so that was important." (Electricity Company 2, 2015, 28 October)
}

Participants remember the 30 minutes preparation as intense because it was a very short time to design sophisticated strategies. For a period of two hours, participants could then trade both electricity and carbon via the trading platform supplied by Paris Bourse. Each session represented one or two years of activity. Over the eight weeks of the role play, the players simulated various time periods between 2000 and 2012. Participants worked out and tested a wide variety of compliance strategies to meet their carbon emissions targets. The virtual companies were rapidly able to develop decision tools to devise strategies in the carbon 
market. They designed tools - primarily Excel tables - to manage their targets costeffectively. These tools enabled them to choose, at different points in time, among a variety of strategies available to them depending on the price of carbon: investment in clean technologies; exchange of carbon credits; purchase of carbon-free electricity and management of production. Participants generally found the role play engaging and fun. When meeting together in more formal occasions at Eurelectric, they would challenge each other on their performances in the role play, which favoured a friendly atmosphere among them.

Among the 16 virtual companies participating, 14 achieved their targets. According to our informants, the two participants that did not achieve their targets may have been attempting to sabotage the experiment in order to discredit market instruments. Alternatively, they may have failed to reach their target due to inconsistent behaviour as they tried to learn to use the new system. Most virtual companies encountered no major difficulties in achieving their targets. This first experimentation triggered an intellectual shift within the electricity sector. As we already mentioned, prior to the role play, electricity companies were rather reluctant towards carbon markets that they assimilated with a carbon constraint. The GETS exercise changed this perspective by enabling electricity companies to learn about carbon markets. More specifically, GETS1 demonstrated that market-based instruments were not constraints per se but rather tools for compliance. Participants observed that carbon trading was costeffective. Some of them even realized that they were making a profit by reaching their environmental targets. Electricity companies came to increasingly view carbon markets in an operational sense:

\footnotetext{
"The main learning from GETS1 was that a carbon market could help reduce compliance costs.” (Eurelectric 1, 2010)
} 
Following the first experimentation, the adoption of a carbon market at the European level became a priority for the electricity sector. To achieve this goal, they needed to develop political alliances with other stakeholders, namely, energy intensive industrial sectors and the European Commission. Furthermore, the electricity sector needed to define in greater detail the prototype market they wished to promote. Only two electricity companies exited the process - the two that had been suspected of sabotaging GETS1.

\section{Using GETS1 to Make Alliances with Key Stakeholders}

Eurelectric presented the results of GETS1 at the Conference of Parties on Climate Change when it met in Bonn in November 1999. In this event, they officially expressed their position in favour of carbon markets.

\footnotetext{
$<$ quotation $>$ In the room, Eurelectric explicitly took position as carbon market promoter. [...] And the electricity companies from other regions did not look very happy about it." (International Energy Agency, 2015, 23 September)
}

The presentation was well received and sparked a constructive dialogue with the European Commission. The Commission informed Eurelectric that it had been exploring the option of carbon markets too. They had mandated several studies on the topic. The resulting Green Paper would constitute the first step in the direction of the adoption of a carbon market. As soon as the Green Paper was published, Eurelectric published a position paper in favour of the European Commission's project. The paper drew attention to the results of GETS1 to specify the conditions under which a carbon market could be adopted (Eurelectric 2000).

Since these developments and during the rest of the policymaking process, the European Commission considered the electricity sector as allies. Through repeated encounters 
and exchanges, Eurelectric was provided with enough information to adjust the timing of GETS to the policymaking process that was going on at the European Commission.

Together with the European Commission, Eurelectric sought to organize a second GETS to convince the other industrial sectors of the usefulness of a carbon market. The relations between the electricity sector and energy intensive sectors were tense on the issue of carbon markets. First, energy intensive companies feared that electricity companies would pass through the cost of carbon and charge them more for electricity. Second, energy intensive companies thought of GETS as a threat - an instrument designed by the electricity industry to further its own interests. Eurelectric sensed that energy intensive sectors would gather and attempt to undermine the policymaking process. The European Commission encouraged Eurelectric to invite these reluctant actors to a second experiment:

\footnotetext{
"The electricity sector has always been very much on board with us, and allies with us, but we didn't want the electricity sector to be the only sector to participate in the ETS. We wanted it to include industry because industry produces a lot of emissions as well through other means than through power generation so we didn't want to stop with electricity and this is why we may have encouraged them to do a GETS2.” (European Commission 1, 2015, 28 September)
}

\section{GETS2 (2000): A Second Experiment with Key Stakeholders}

To involve the rest of industry in the policymaking process, Eurelectric invited the members of six additional industrial sectors to take part in GETS2. The newcomers were selected according to the sectors mentioned in the European Commission's Green Paper: metallurgy, oil and refining, chemicals, glass, construction materials and paper. Eurelectric also invited 
two financial institutions to take part in the exercise as they believed financial institutions would have a role to play also in such policy mechanisms.

The industries mentioned in the Green Paper had misgivings about carbon markets, which they feared would have negative effects on their competitiveness. In this context, Eurelectric's ambition was to demonstrate the advantages of market-based mechanisms in terms of companies' competitiveness, compared to other policy instruments; and to rehabilitate market instruments by demonstrating their environmental integrity (their ability to efficiently reduce carbon emissions from the industry).

\section{Collective Bricolage on the Prototype}

To enhance the scope of GETS, Eurelectric decided to redesign the prototype through a process that we qualify as collective bricolage. Building on the first prototype, Eurelectric invited all the participants to make proposals and refine its architecture. The ambition was both to pacify the relations amongst industrial actors that had diverging interests towards carbon markets and enrol other key stakeholders of the policymaking process. As a result, three carbon market prototypes were created with original features that integrated multiple strategic views.

All the participants were invited to get involved in designing the rules of the new carbon market prototype. They could make any proposal to change the architecture of the original prototype. Eurelectric had hired a consulting company to coordinate the bricolage process. The objective was to accept as many proposals as possible, provided that it would be easy to implement. Only the experiment would reveal their robustness, not ex ante negotiations. This open-ended process was set up as a way to pacify relations amongst 
industrial participants and favour a bottom up appropriation process. A member of Eurelectric explains this design strategy as follows:

\footnotetext{
"There was no way that, as utilities, we would impose rules that would apply to other industrial actors. The process had to be much more creative. They [the energy intensive sectors] had to feel represented in the design. This is also why we chose a neutral agent to coordinate the operations. We did not want to give the impression that we were imposing our point of view. We wanted to produce collective knowledge on carbon markets so we could talk with the regulator." (Eurelectric 2, 2015, 23 September)
}

The collective design process was successful and yielded a wide variety of proposals that were aligned with the interests of the participants. For instance, several companies suggested new allocation methods for carbon emissions allowances. Most industry players were in favour of prorating allowances according to previous emissions. The advantage of this system was that companies would receive their allowances free of charge according to their past emission profile, which enabled them to gradually reduce their emissions over time. A cement company advocated allocation according to a benchmarking system. This method consisted of calculating allocations according to a fictitious situation in which the production of the same quantity of cement would mobilize the most efficient technologies. This allocation method had the advantage of encouraging technology transfer. Such systems are most effective in sectors in which the carbon intensity of production technologies varies strongly from one company to another, which it does in the cement sector. Lastly, an electricity company recommended testing auctions. The auction method was recognized by economists as the one 
that enhances the overall efficiency of market-based instruments. In theory, this method would accelerate the generation of a carbon price.

The European Commission was also on board as an advisor in the design process. The role of the Commission in GETS was informal but did nevertheless provide considerable input. This cooperation helped Eurelectric to ensure consistency between the European Commission's view and the industrial view. Certain features of the prototype were also added to ensure consistency between GETS and other initiatives going on in Europe. Amongst others, a mechanism called 'gateway' was added to ensure consistency with the United Kingdom's initiative, namely, the Climate Change Levy.

\footnotetext{
"We knew that the implicit involvement of other actors through the gateway and other mechanisms would help us build a dialogue." (Electricity Company 1, 2015, 23 September)
}

This strategy proved crucial to enter into a dialogue with key institutional actors in Europe.

\section{Staging a Demonstration of Three New Prototypes}

The role play of GETS2 unfolded almost identically as in GETS1. To test the three prototypes, three separate role plays were organized. The complete exercise lasted 6 months, from January to July 2000. Each Wednesday, the participants would connect to an Internet platform designed by the organizers, and proceed to engage in carbon and electricity trading.

To make the role play more realistic than in GETS1, the organizers called on a consulting firm to design new algorithms and protocols. 'Accidents' were introduced randomly in the course of the game to simulate fluctuations linked for instance to political 
cycles and geopolitical conflicts. As a result, each virtual company faced a 4 per cent surge in its electricity demand during one of the sessions. Whereas the first experimentation allowed electricity trading only in the spot market, the second permitted trading in the futures market so as to better approximate the real-world behaviour of electricity suppliers. ${ }^{2}$ Other measures were taken to stabilize prices in the long-term. Eventually, to ensure consistency between recent political developments at the United Nations and the role play, the organizers decided to simulate one of the market mechanisms established by the Kyoto Protocol and to test its compatibility with the prototype carbon market. As a consequence, the strategies companies devised during GETS2 were more sophisticated and realistic than in GETS1. They were also more compatible with real conditions and debates, which facilitated their transposition.

\section{The Effects of GETS2: Alliance with Key Stakeholders}

The intellectual impact of GETS2 was similar to that of GETS1, but this time it applied to the industry as a whole. The participants understood that market-based instruments were not constraints per se but tools to help them reach compliance. The players had learned to use the carbon price as a signal to trigger investment choices and trading strategies. The participants also found that the trading system had advantages in managerial and environmental terms. From the point of view of the management of the carbon variable, the carbon price provided a simple and clear signal for decision-making. Compared to any other carbon regulation mechanism, emissions trading would make it possible to achieve carbon compliance at the lowest cost. Highlighting the role of a carbon price in economic optimization was a key achievement of GETS2: 


\begin{abstract}
"An electricity-carbon market made it possible to obtain a clear and objective price signal, allowing industrial companies to determine a cost of energy 'carbon included'. This cost, related to the various market prices played an important role and allowed economic optimisation strategies to be designed." (GETS2, p. 7).
\end{abstract}

From the environmental point of view, the experiment demonstrated that market mechanisms systematically achieved the environmental objective (unlike the other policy instruments such as taxes). Most importantly, it removed the negative view of carbon markets that had prevailed in some segments of the industry:

"The role play highlighted the key elements needed to convince the rest of
industry. It disproved the negative connotations ascribed to this type of instrument,
such as the concept of constraint and the right to pollute." (Electricity Company 1, 2012)

The GETS experiment won over not only the heads of climate projects - who were already familiar with these issues - but also a wide range of other organizational members within the companies:

\footnotetext{
"The experiment convinced my colleagues within the company who knew nothing about emissions trading - especially the financial people." (Cement company 1 , 2011).
}

GETS2 generated effects beyond the European industry, as confirmed by the 2000/87/EC Directive adopted in 2003 establishing a pilot market. One of the three prototypes tested had 
reached consensus among participants. Most of the participants expressed that if a European carbon market were to exist, the best strategy (in the GETS experiment) would be to implement the prototype tested in GETS2.1. It is not very surprising then that the EU-ETS pilot that was implemented after the stakeholder consultation was identical to GETS2.1's prototype.

\section{The Role of GETS in the Policymaking Process}

In 2000, the European Commission organized a consultation of European carbon market stakeholders to negotiate the architecture of this market. The consultation was more than a lobbying forum. Members of the European Commission described it as a milestone in the collective learning process that eventually led to the EU-ETS:

"The consultation was a process of intense sense making. Remember that in 2001, carbon markets were highly exotic objects." (European Commission 2, 2011).

Companies that had participated in GETS shared their experience with the ones that knew less about emissions trading. GETS was not the only exercise to fuel discussions. The governments of the United Kingdom and Denmark as well as a number of companies had run their own experimentations (Akhurst et al. 2003; Braun 2009; Christiansen and Wettestad 2003; Victor and House 2006; Wettestad 2005). Despite technical differences among them, all these experimentations played a considerable role in the collective sense-making that was necessary to push further the policymaking process: 


\begin{abstract}
"All these trading schemes, although very imperfect, were very important in building the consensus needed for this different policy instrument to be implemented . . . because there was a mistrust of it. But the models, the exercises we did, they helped familiarise, understand and even see the benefits and the advantages." (European Commission 1, 2015, 23 September)
\end{abstract}

The power sector as well as government representatives engaged dynamically in the discussions. Several market prototypes were presented during these discussions, which were all very different from the GETS prototype. The United Kingdom submitted a proposal for a particularly complex model that combined a carbon tax and allowance markets. BP, which had tested a carbon market internally in 1998, also presented its mechanism and submitted proposals based on it.

According to our informants both at the European Commission and in the industry, GETS had more impact on the policymaking process than did the other prototypes. Several factors might help explain it. First of all, its design was very simple, especially in comparison to the mechanism proposed by the United Kingdom. Second, it had been tested and shared by most of the stakeholders present at the consultation meetings, providing a base of shared knowledge.

One year after the consultation, the European Commission presented the first EU-ETS proposal at an official event held as part of the annual international climate conference in Marrakesh. On that occasion, the Commission invited Eurelectric to present the GETS initiative and its main results.

DISCUSSION: COLLECTIVE BRICOLAGE AND STAGING POLICYMAKING 
The case described the efforts of a private association to influence policymaking despite significant reluctance among both industrial players and policymakers. In many aspects, the case is a classical story of influence and power in political arenas where a skilled leading actor provokes a radical shift in the general opinion. The originality of the case is to reveal a rather unexpected influence strategy revolving around two elements: collective bricolage and staging. Here, collective bricolage served to dynamically recombine the interests of different stakeholders into a prototype for a carbon market. Eurelectric also staged an experimentation on carbon markets to diffuse the GETS results into key political spheres to convince wider circles of stakeholders to engage with, and support, the prototype.

\section{Collective Bricolage}

Collective bricolage played an important role in Eurelectric's initiative to co-construct a carbon market with other players in the industry. By bricolage, we mean the act of recombining heterogeneous propositions from multiple domains (for example from the cement industry, electricity sector, non-governmental agencies) into an original arrangement (Baker and Nelson 2005; Carstensen 2011; Højgaard Christiansen and Lounsbury 2013; Duymedjian and Rüling 2010). Eurelectric organized collective bricolage sessions with key stakeholders of the climate political arena as a way to engage them in the notion of carbon markets. All GETS participants were invited to make proposals to the carbon market's design and test these proposals through a role play. The design of the carbon market prototype used in GETS was thus the outcome of collective bricolage.

The composition of the prototype crystallized the political strategies of participants and their potentially conflicting interests and representations. For instance, some electricity utilities from the United Kingdom proposed to introduce a 'gateway system' that was being 
tested by their government. Their alternative proposal reveals their involvement in policymaking with their government. Indeed, since 1999, the electricity sector in the UK had been working with its national government on a semi-voluntary framework for carbon emissions management. Following the demand of the electricity sector in the UK, this system was introduced and tested in GETS2. Similarly, the request of Lafarge, a major European cement company, to implement technology standards reveals its political implication at the international level to promote sectoral agreements on carbon that are based on benchmarks. As it appears, the multiple orientations promoted by the participants for the carbon market design were not easily compatible with one another. To convince the cement sector, consultants were hired to design a sophisticated algorithm for benchmark allocations. To enrol the Italian industry, sophisticated carbon accounting methods had to be imagined to ensure environmental integrity. Testing the gateway proposed by the UK's electricity utilities also raised some arduous technical challenges for the organizers. The GETS role plays allowed heterogeneous actors to try out different proposals in practice and collectively construct a model that appealed to all, or most, participants.

We propose that bricolage - instead of a multi-stakeholder negotiation - helped alleviate the challenge of initial conflicting viewpoints and preferences. Instead of being negotiated, various propositions were tested in the role plays and their effects were discussed collectively afterwards. Every implementable proposition was tested, and promising features from different models were combined and tested as well. Collective bricolage worked as an instrument of dialogue that harmonized the interests of participants. Collective bricolage should not, however, be understood as a simple matter of integrating whatever proposition actors submit to a policymaking process. It requires considerable engineering effort to design tools and algorithms that enable selected features from multiple proposals to work well together. 
To sum up, collective bricolage appears as a promising approach to analyse policymaking in as much as it allows stakeholders that do not initially share the same interests and understandings to work together towards the crafting of a collective model. In collective bricolage, stakeholders are encouraged to project and hybridize their respective representations and interests onto 'a boundary object' that operates as an arena of negotiation.

\section{Staging}

In the GETS case study, staging an experimentation of carbon markets was central to building influence, strategies and policymaking. It played two central roles: learning and demonstration. Eurelectric first used GETS as a learning device to provoke the intellectual shift that they needed in the private sector to promote carbon markets. All the participants in GETS shifted their point of view on carbon markets once they experienced it in practice. Before GETS, the participants would mostly be opposed to these market instruments that they perceived to be a constraint. After GETS, participants saw carbon markets as efficient tools for compliance instead. The two German companies that left the experiment after the first round were convinced too. They decided to promote voluntary agreements at the national level but they could understand the interest of carbon markets at the European level if such a regulation was to come.

The European Commission that closely followed the experiment was pleased that the results demonstrated that carbon markets worked the way they were supposed to work. Such demonstration was key to influence other key stakeholders that did not participate in the experiment. Along with the policymaking process, Eurelectric organized a large diffusion operation based on the GETS results. Eurelectric's representatives presented the GETS results in strategic political arenas such as the United Nation's climate summits and the stakeholder 
consultations organized by the European Commission. The European Commission officially invited Eurelectric during the United Nation's climate summit of Marrakesh to present the GETS results. Eurelectric's representatives also presented the GETS results to the European Parliament as well as to foreign governments and companies. The fact that GETS had actually demonstrated that carbon markets worked in practice proved crucial to convince key stakeholders in these instances.

If the experiment had depicted an unrealistic prototype, its results would not be relevant to 'real world' debates. For staging operations to be successful, considerable attention must be directed to technical details. In GETS, intense engineering helped the results spread outside the experiment. Apparently insignificant details had been reproduced with a high degree of precision. This mimicking of real conditions is very important, we contend, for the success of a staging operation.

\section{CONCLUSIONS}

This chapter describes two activities that companies strategically display to influence policymaking processes: collective bricolage and staging. These activities are by no means an exhaustive list of lobbying strategies that can be deployed at the organization level. Neither do they ensure success in influencing key stakeholders in political arenas. Nevertheless, we believe these components of effective policymaking to merit further investigation. They should be looked at in more detail if we want to better understand how the private sector influences policymaking (Bonardi et al. 2005).

We believe that collective bricolage is becoming an increasingly relevant concept for shedding light on the collective nature of policymaking, which is particularly visible in the 
field of environmental/climate regulations (Braun 2009; Callon 2009; Wettestad 2005). Indeed, emerging issues such as the climate change initiative that we describe in this chapter, and environmental issues more generally, are characterized by both unstable and lacunar scientific knowledge (Godard 2004). Under such conditions, policymakers rarely have the means to design regulations in isolation. These complex issues call for the participation of actors that are not traditionally involved in policymaking processes such as private associations and scientific NGOs. We propose that the concept of collective bricolage is particularly well suited to reveal the mechanisms at play when heterogeneous actors seek to find a consensus on policy alternatives. We thus call for further scholarly analysis of the processes of collective bricolage in policy studies.

Staging is the second analytical concept that emerged from our study for describing strategies of influence in the context of policymaking. Compared to bricolage, staging is more aligned with what is usually described as being classical lobbying strategies. Our case indicates that staging a demonstration of policy innovations that targets key audiences can be a highly influential activity. Studies of the role of 'demonstration' in the making of economic policies are gaining momentum in the social studies of market literature (MacKenzie et al. 2007). In particular, the very places where staging takes place, such as platforms (Muniesa and Callon 2007), hybrid forums (Callon et al. 2001) and political arenas in general merit attention in future studies of contemporary policymaking.

\section{NOTES}


${ }^{1}$ EU-ETS stands for the European Emissions Trading System. It was launched in 2005 as a pilot carbon market.

${ }^{2}$ A spot market is a financial market in which commodities are traded and delivered in real time. In futures markets, delivery is expected at a later date.

\section{REFERENCES}

Aggeri, F. (1999), 'Environmental policies and innovation: A knowledge-based perspective on cooperative approaches', Research Policy, vol 28 (7), 699-717.

Akhurst, M., J. Morgheim and R. Lewis (2003), 'Greenhouse gas emissions trading in BP', Energy Policy, 31 (7), 657-63.

Baker, T. and R.E. Nelson (2005) 'Creating something from nothing: Resource construction through entrepreneurial bricolage', Administrative Science Quarterly, 50, 329-66.

Baron, D. (1995), 'Integrated strategy: Market and nonmarket components', California Management Review, 37 (2), 47-65.

Baron, D. (1999), 'Integrated market and nonmarket strategies in client and interest group politics', Business and Politics, 1 (1), 7-34.

Baron, D. and D. Diermeier (2007), 'Strategic activism and nonmarket strategy', Journal of Economics and Management Strategy, 16 (3), 599-634.

Bonardi, J.P., A. Hillman and G. Keim (2005), 'The attractiveness of political markets: Implication for firm strategy', Academy of Management Review, 30 (2), 1209-28.

Braun, M. (2009), 'The evolution of emissions trading in the European Union - The role of policy networks, knowledge and policy entrepreneurs', Accounting, Organizations and Society, 34 (3-4), 469-87. 
Burtraw, D. and S.J. Szambelan (2009), 'U.S. emissions trading markets for $\mathrm{SO}_{2}$ and $\mathrm{NO}_{\mathrm{x}}$ ', Resources for the Future, Discussion Paper, DP 09-40.

Callon, M. (2009), 'Civilizing markets: Carbon trading between in vitro and in vivo experiments', Accounting, Organizations and Society, 34 (3-4), 535-48.

Callon, M., P. Lascoumes and Y. Barthe (2001), Agir dans un monde incertain. Essai sur la démocratie technique, Paris: Le Seuil.

Carstensen, M. (2011), 'Paradigm man vs. the bricoleur: an alternative vision of agency in ideational change', European Political Science Review, 3, 147-67.

Cass, L.R. (2005), 'Norm entrapment and preference change: The evolution of the European Union position on international emissions trading', Global Environmental Politics, 5 (2), 38 60. The MIT Press.

Christiansen, A.C. and J. Wettestad (2003), 'The EU as a frontrunner on greenhouse gas emissions trading: how did it happen and will the EU succeed?', Climate Policy, 3 (1), 3-18. Convery, F. (2009), 'Origins and Development of the EU ETS', Environmental and Resource Economics, 43 (3), 391-412.

Damro, C. and P. Mendez (2003), 'Emissions trading at Kyoto: from EU resistance to Union innovation', Environmental Politics, 12 (7), 71-94.

Duymedjian, R. and C.C. Rüling (2010) 'Towards a foundation of bricolage in organization and management theory', Organization Studies 31, 133-51.

Eisenhardt, K.M. and M.E. Graebner (2007), 'Theory building from cases: Opportunities and challenges', Academy of Management Journal, 50 (1), 25-32.

Godard, O. (2004), 'Le casse-tête de l'effet de serre au crible du développement durable', Risques et management international, 3, pp. 13-35.

Højgaard Christiansen, L. and M. Lounsbury (2013), 'Strange brew: Bridging logics via institutional bricolage and the reconstitution of organizational identity', in M. Lounsbury and E. Boxenbaum (eds) Institutional Logics in Action, Part B, Bingley: Emerald Group 
Publishing Limited, pp. 199-232 (Research in the Sociology of Organizations, Vol. 39 Part B).

Holburn, G. and R. Vanden Bergh (2008), 'Making friends in hostile environments: Political strategy in hostile environments', Academy of Management Review, 33 (2), 521-40.

Lévi-Strauss, C. (1962), La pensée sauvage, Paris: Plon.

Lévi-Strauss, C. (1966), The savage mind, Chicago: University of Chicago Press.

MacKenzie, D.A., F. Muniesa and L. Siu (2007), Do economists make markets?: on the performativity of economics, Princeton: Princeton University Press.

Montgomery, W. (1972), 'Markets in licenses and efficient pollution control program', Journal of Economic Theory, 5, 395-418.

Muniesa, F. and M. Callon (2007), 'Economic experiments and the construction of markets', in D. MacKenzie, F. Muniesa and L. Siu (eds), Do economists make markets? On the performativity of economics, Princeton: Princeton University Press, pp. 161-89.

Newell, P. and M. Paterson (1996), 'From Geneva to Kyoto: the second conference of the Parties to the UN Framework Convention on Climate Change', Environmental Politics, 5, $729-35$.

Newell, P. and M. Paterson (1998), 'A climate for business: global warming, the state and capital', Review of International Political Economy, 5 (4), 679-703.

Skjærseth, J.B. and J. Wettestad (2008), 'Implementing EU emissions trading: success or failure?', International Environmental Agreements: Politics, Law and Economics, 8 (3), 27590.

Victor, D.G. and J.C. House (2006), 'BP's emissions trading system', Energy Policy, 34 (15), $2100-12$.

Wettestad, J. (2005), 'The making of the 2003 EU Emissions Trading Directive: An ultraquick process due to entrepreneurial proficiency?', Global Environmental Politics, 5 (1), 123. 